\title{
BDNF Injected into the Superior Colliculus Reduces Developmental Retinal Ganglion Cell Death
}

\author{
Yun-Tao Ma, ${ }^{1}$ Ted Hsieh, ${ }^{1}$ M. Elizabeth Forbes, ${ }^{2}$ James E. Johnson, ${ }^{2}$ and Douglas O. Frost ${ }^{1}$ \\ ${ }^{1}$ Department of Pharmacology and Experimental Therapeutics, University of Maryland School of Medicine, Baltimore, \\ Maryland 21201, and 2Department of Neurobiology and Anatomy, Bowman-Gray School of Medicine, Winston-Salem, \\ North Carolina 27157
}

The role of neurotrophins as survival factors for developing CNS neurons, including retinal ganglion cells (RGCs), is uncertain. Null mutations for brain-derived neurotrophic factor (BDNF) or neurotrophin 4 (NT4), individually or together, are without apparent effect on the number of RGCs that survive beyond the period of normal, developmental RGC death. This contrasts with the BDNF dependence of RGCs in vitro and the effectiveness of BDNF in reducing RGC loss after axotomy. To investigate the effect of target-derived neurotrophins on the survival of developing RGCs, we injected BDNF into the superior colliculus (SC) of neonatal hamsters. At the age when the rate of developmental RGC death is greatest, BDNF produces, $20 \mathrm{hr}$ after injection, a 13-15-fold reduction in the rate of RGC pyknosis compared with the rates in vehicle-injected and untreated hamsters. There is no effect $8 \mathrm{hr}$ after injection. Electrochemiluminescence immunoassay measurements of BDNF protein in the retinae and SC of normal and BDNF-treated hamsters demonstrate that the time course of BDNF transport to RGCs supports a role for target-derived BDNF in promoting RGC survival. The effectiveness of pharmacological doses of BDNF in reducing developmental RGC death may be useful in further studies of the mechanisms of stabilization and elimination of immature central neurons.

Key words: brain-derived neurotrophic factor; cell death; development; hamster; neurotrophin; retina; visual system; pyknosis
In many CNS regions, developing neurons and their connections are overproduced and then partially eliminated (Cowan et al., 1984). In normal rodents, $\sim 65 \%$ of developing retinal ganglion cells (RGCs) die (Sefton and Lam, 1984; Crespo et al., 1985; Tay et al., 1986) by pyknosis (Rehen and Linden, 1994). Immature peripheral sensory and sympathetic neurons survive by competing for target-derived neurotrophins (for review, see Cowan et al., 1984; Oppenheim, 1991; Lewin and Barde, 1996). The survivalpromoting effects of neurotrophins on developing CNS neurons are controversial. Neurotrophins are retrogradely transported by CNS neurons (DiStefano et al., 1992) and promote the survival of these neurons in vitro (for review, see Korsching, 1993). Excess, afferent-derived neurotrophins reduce the developmental death of CNS neurons (Alonso-Vanegas et al., 1996; Johnson et al., 1997). Neurotrophins slow or reduce axotomy-induced death of CNS neurons (Hefti, 1986; Kromer, 1987; Sendtner et al., 1992; Yan et al., 1992; Alcántara et al., 1997), including developing (Rabacchi et al., 1994; Cui and Harvey, 1995; cf. Weibel et al., 1995) and mature (Carmingnoto et al., 1989; Mey and Thanos, 1993; Mansour-Robaey et al., 1994) RGCs. Although immature CNS neurons require trk receptor signaling for survival (Alcánt-

\footnotetext{
Received Nov. 21, 1997; accepted Dec. 19, 1997.

This work was supported by National Institutes of Health Grants MH49568 and EY11434 (D.O.F.) and EY11127 (J.E.J.), National Institutes of Health Training Grant NS07375 (Y.-T.M.), and a Special Research Initiative Support Grant from the University of Maryland (D.O.F.). The human recombinant BDNF and rabbit polyclonal anti-BDNF antibody were generous gifts of Amgen (Thousand Oaks, CA) The antibody was produced by Q. Yan. We thank Chris von Bartheld, Peter Clarke, Paul Fishman, Bruce Krueger, and Ron Oppenheim for helpful discussions and critical comments on this manuscript.

Correspondence should be addressed to Dr. Douglas O. Frost, Department of Pharmacology and Experimental Therapeutics, University of Maryland School of Maryland, 655 West Baltimore Street, Baltimore, MD 21201.

Copyright (C) 1998 Society for Neuroscience $\quad 0270-6474 / 98 / 182097-11 \$ 05.00 / 0$
}

ara et al., 1997), null mutations for neurotrophins or their receptors generally have minimal effects on the definitive number of CNS neurons (Snider, 1994), including RGCs (Cellerino et al., 1997). However, the "knock-out" paradigm presents many interpretive difficulties (Johnson and Oppenheim, 1994), and careful quantitative studies have demonstrated that neurotrophin knockouts can reduce some CNS neuron populations (Schwartz et al., 1997).

The single example of target-derived neurotrophins promoting the survival of immature, CNS neurons in vivo is the effect of retinal brain-derived neurotrophic factor (BDNF) on chick isthmo-optic neurons (von Bartheld et al., 1994; Primi and Clarke, 1996). In neonatal rats, exogenous BDNF reduces the density of pyknotic figures in the corpus striatum (Mahalik and Altar, 1996), and neurotrophin 4 (NT4) (but not BDNF) reduces the rate of RGC death (Cui and Harvey, 1994); in chicks, BDNF reduces the elimination of RGCs in an early phase of cell death (Frade et al., 1997). In all these latter studies, neurotrophins were applied to neuronal somata, so the action of target-derived factors could not be assessed.

In vitro, BDNF (Thanos et al., 1989) and NT4 (Cohen et al., 1994) increase the survival of developing rat RGCs, although RGC responsiveness to BDNF declines after embryonic day 17 (E17) (Johnson et al., 1986; Castillo et al., 1994). Survival of rat RGCs is increased by the combination of other factors with neurotrophins and by the activation of second messenger cascades associated with neuronal depolarization (Meyer-Franke et al., 1995). NGF (Lehwalder et al., 1989) and BDNF (RodriguezTebar et al., 1989) promote chick RGC survival. BDNF increases Xenopus RGC survival, although the effect may be partially by autocrine or paracrine loops (Cohen-Cory and Fraser, 1994; Cohen-Cory et al., 1996). 
The temporal and spatial patterns of neurotrophin and trk receptor expression are consistent with neurotrophins promoting the survival of immature RGCs in vivo. TrkA, trkB, and trkC are expressed in developing rodent RGCs (Ernfors et al., 1992; Zanellato et al., 1993; Koide et al., 1995; Rickman and Brecha, 1995; Ugolini et al., 1995); trkB is expressed in mature rodent (Jelsma et al., 1993) and developing ferret (Allendoerfer et al., 1994) RGCs. Immature chick and Xenopus RGCs express trkB and trkC (Rodriguez-Tebar et al., 1993; CohenCory and Fraser, 1994; Escandon et al., 1994; Okazawa et al., 1994; Garner et al., 1996; Hallböök et al., 1996). p75 is expressed by developing ferret (Allendoerfer et al., 1994), rat (Koide et al., 1995), and chick (von Bartheld et al., 1991) RGCs. In the chick tectum, BDNF protein concentrations increase from E4 through hatching. This epoch includes the periods when RGC axons invade the tectum and elaborate their terminal arbors and when programmed RGC death is maximal; after axonal maturation is complete, tectal BDNF concentration falls (Johnson et al., 1996). In the hamster superior colliculus (SC), BDNF levels and the development of RGCs and their axons are similarly related (Ma et al., 1997). BDNF is present in the SC of adult rodents (Hofer et al., 1990; Wetmore et al., 1990; Ma et al., 1997). Intracollicularly injected BDNF is retrogradely transported by RGCs (Fournier et al., 1997; Herzog and von Bartheld, 1997).

To investigate the role of target-derived neurotrophins as survival factors for developing RGCs, we injected BDNF into the SC of Syrian hamsters 8 or $20 \mathrm{hr}$ before killing them on postnatal day $4(\mathrm{P} 4$; first $24 \mathrm{hr}$ after birth $=\mathrm{P} 0)$, when the rate of programmed RGC death is greatest (Sengelaub et al., 1986). Twenty hours, but not $8 \mathrm{hr}$, after BDNF treatment, there was a significant reduction in the rate of RGC pyknosis. Measurements of BDNF protein in the retina and $\mathrm{SC}$ demonstrated the time course of accumulation of exogenous BDNF in those structures.

\section{MATERIALS AND METHODS}

Subjects and surgery. Syrian golden hamsters (Mesocricetus auratus) were used in this study. Different groups of animals were subjected to varying combinations of injections of the fluorescent retrograde tracer diamidino yellow (DY) (Keizer et al., 1983), human recombinant BDNF (Amgen, Thousand Oaks, CA), or vehicle. Various combinations of treatments and survival times were used (see Fig. 2). Hamsters receiving DY injections were anesthetized by hypothermia on the day after birth (P1). The scalp was incised, and a glass injection pipette (tip diameter, $50 \mu \mathrm{m}$ ) was lowered through a small hole in the skull. In each SC, $0.1 \mu$ l of DY ( $2 \%$ in $\mathrm{H}_{2} \mathrm{O}$ ) was injected at a site near the center of the SC and $400 \mu \mathrm{m}$ deep to the dorsal surface. Each injection was made over 2 min using a Picospritzer. At the end of each injection, the pipette was left in situ for 2 min before being withdrawn slowly to minimize reflux on withdrawal. The scalp was then sutured shut, and the hamsters were reanimated and returned to their mothers. Hamsters receiving BDNF or vehicle injections were anesthetized by inhalation of Halothane $\left(0.5-1.5 \%\right.$ in $\left.\mathrm{O}_{2}\right)$ on P3 (for 12 or $20 \mathrm{hr}$ survival after injection) or early on P4 (for $8 \mathrm{hr}$ survival after injection). In each SC, $0.33 \mu \mathrm{l}$ of BDNF $(0.1 \mu \mathrm{g} / \mu \mathrm{l}$ in $0.1 \%$ BSA in PBS) or vehicle was pressure injected at each of three sites (spaced equidistantly from each other and from the border of the SC and $400 \mu \mathrm{m}$ deep to the dorsal surface), using a technique identical to that used for DY injection. BDNF and vehicle injections were bilateral in the hamsters used in the experiments on RGC pyknosis. This procedure ensured that the axons of both ipsilaterally and contralaterally projecting RGCs were exposed to the solution injected. Injections were unilateral in the hamsters used in the experiments on BDNF transport.

Quantitative studies of RGC pyknosis. Hamsters used to study the rate of RGC pyknosis were killed on P4 by an overdose of Nembutal given intraperitoneally. The hamsters were perfused transcardially with $4 \%$ paraformaldehyde in $\mathrm{PO}_{4}$ buffer, and their eyes were enucleated. The cornea, iris, lens, and vitreous were rapidly removed from each eye, and the retina was dissected from the eye cup in cold $\mathrm{PO}_{4}$ buffer $\left(4^{\circ} \mathrm{C}\right)$. Four relieving cuts were made along radii lying at $45^{\circ}$ angles to the principal axes of the retina. The retinae were then whole mounted, vitreal side up, on small squares of black nitrocellulose paper, which were placed on a glass slide and coverslipped with glycerol-gelatin (Sigma, St. Louis, MO). Some retinae were stained after dissection with Hoechst dye $(0.1$ $\mu \mathrm{g} / 100 \mu \mathrm{l} ; 3 \mathrm{hr}$ at $20^{\circ} \mathrm{C}$ ) and rinsed in PBS before mounting on nitrocellulose paper.

All retinae were initially surveyed to verify that they were well preserved. In DY-treated hamsters and hamsters the retinae of which were stained with Hoechst dye postmortem, we also checked to ensure that nuclei in the RGC layer were well labeled with DY and Hoechst dye, respectively, throughout the retina. Retinae not meeting these criteria were discarded. To avoid any bias in the results, we used a blind data collection technique. All retinae used for nuclear counts were coded so that the person doing the counting (Y.-T.M.) did not know the treatment history of the animals from which they were obtained; no results were revealed to him until the completion of data collection for the entire study.

All cell counts were made on a computer-assisted fluorescent microscope system (Neurotrace) using a $100 \times$ oil immersion objective and an ultraviolet filter set. In different experiments, we counted either DYlabeled or Hoechst dye-labeled nuclei in the ganglion cell layer of the retina (see below). In each retina, we counted the number of healthy (chromatin not clumped; Fig. 1) nuclei and the number of pyknotic (clumped chromatin; Fig. 1, arrows, arrowheads) nuclei in four square sectors. The sectors were each $57,600 \mu \mathrm{m}^{2}$ and centered $\sim 0.92 \mathrm{~mm}$ from the optic disk along radii directed toward the dorsal, ventral, temporal, and nasal poles of the eye. For each sector (or for all four sectors pooled together), the number of pyknotic nuclei is divided by the total number of nuclei (healthy + pyknotic) to obtain the percentage of RGCs that are pyknotic. This index is more reliable than are counts of the total numbers of pyknotic and healthy nuclei, because, for many reasons, there is significant intra- and interanimal variability in the raw numbers but much less variability in the percentages. Different experimental groups were compared with respect to the frequency of pyknotic nuclei using the Mann-Whitney $U$ test. To ensure the consistency of the observer's criteria for identifying normal and pyknotic RGCs, the observer recounted three retinae blind at the completion of the study. The fractions of pyknotic RGCs obtained were within $4 \%$ of the original fractions for these retinae.

Analysis of BDNF transport. Hamsters used to study the transport to the retina of exogenous BDNF injected into the $\mathrm{SC}$ were killed on $\mathrm{P} 4$ by an overdose of Nembutal given intraperitoneally. The hamsters were enucleated, and the cornea, iris, lens, and vitreous were rapidly removed from each eye in $\mathrm{PO}_{4}$ buffer $\left(4^{\circ} \mathrm{C}\right)$. The retinae were then dissected free from the remaining ocular tissues. Retinae were then separately weighed and snap frozen in isopentane cooled in liquid nitrogen. The brains of the hamsters were removed from the skull, and the SC or the olfactory bulbs on the two sides were dissected separately in $\mathrm{PO}_{4}$ buffer $\left(4^{\circ} \mathrm{C}\right)$, weighed, and snap frozen. The amount of BDNF protein in the eyes and brains was determined using the electrochemiluminescent immunoassay (ECLIA) (Blackburn et al., 1991; Yang et al., 1994; Johnson et al., 1995). For hamsters that received either no injections or unilateral intracollicular injections of vehicle before being killed on $\mathrm{P} 4$, three retinae were pooled in each sample processed for ECLIA (see Table 2). This is because of the small amount of BDNF in individual retinae. Retinae from hamsters injected with BDNF were processed individually for ECLIA.

$B D N F$ extraction for ECLIA. BDNF was extracted from hamster SC and retinae according to procedures described in detail elsewhere (Johnson et al., 1995, 1996). In preliminary experiments, we determined the conditions for maximal recovery of endogenous BDNF from the hamster retina and SC. Normally, a critical parameter, the dilution of tissue in homogenization buffer, is considered to be optimized when increasing dilution of the tissue no longer results in an increase in recovered BDNF. However, over the range of dilutions that we tested (for SC, $1 \mathrm{mg}$ of tissue $/ 25 \mu \mathrm{l}$ of buffer to $1 \mathrm{mg}$ of tissue/200 $\mu \mathrm{l}$ of buffer; for retina, 1:25 to $1: 100 \mathrm{mg} / \mu \mathrm{l})$, the recovery of BDNF continued to increase. Because increased dilutions of tissue would have begun to affect adversely the sensitivity of our ECLIA assay, all of the measurements obtained must be regarded as minimum estimates of tissue BDNF levels. Comparisons of measurements obtained from different tissue samples accurately reveal differences in the relative amounts of BDNF in the samples but not absolute differences. In all of the assays reported in this study, retinae were diluted at $1: 75$ or 1:100, and SC were diluted at 1:150 or 1:200. 

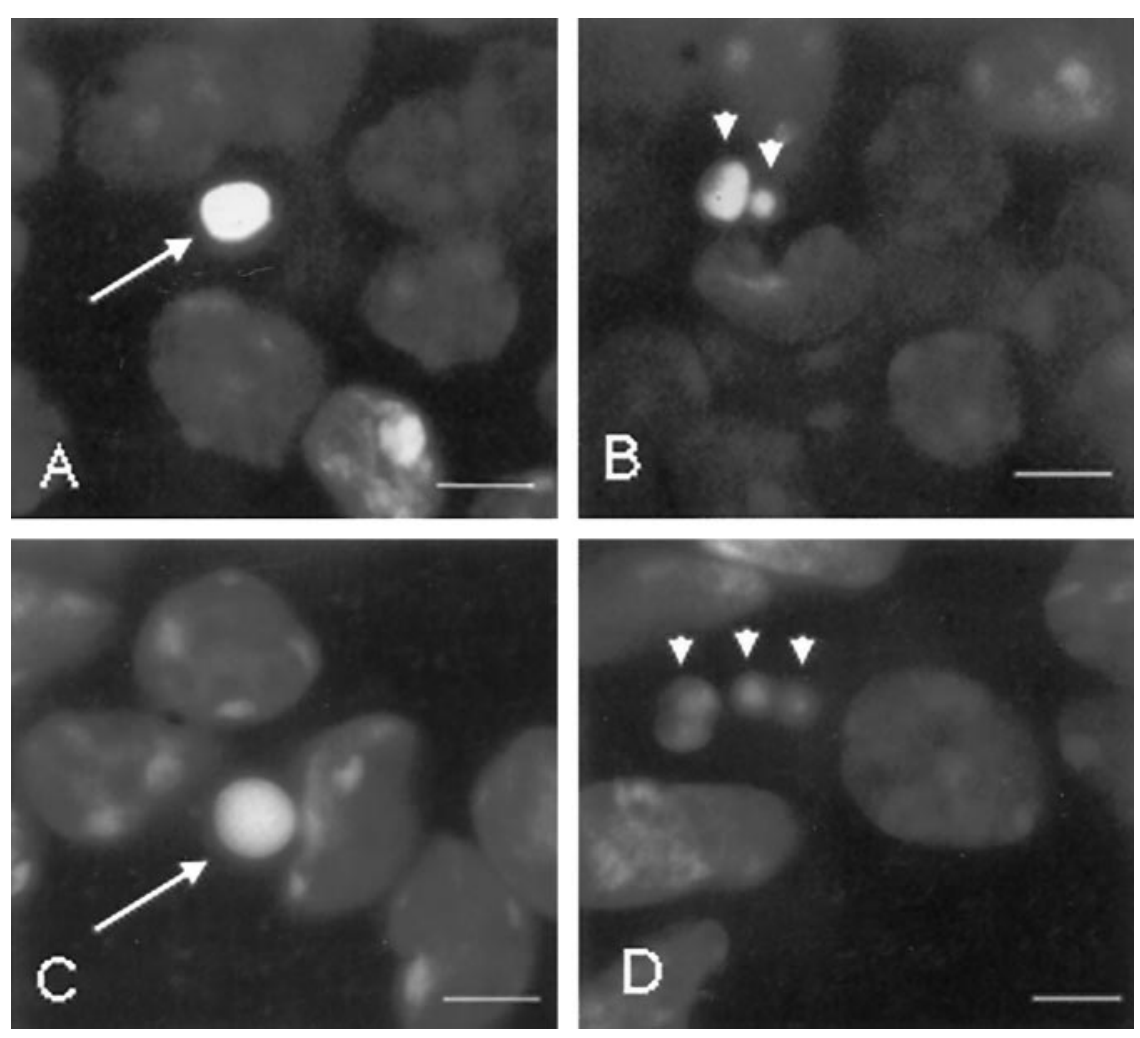

Figure 1. Micrographs showing normal and pyknotic RGC nuclei in normal hamsters on P4. $A, B$, All nuclei are stained by retrograde transport of diamidino yellow injected into the SC. $C, D$, All nuclei are stained postmortem with Hoechst dye. Arrows indicate pyknotic nuclei in which the chromatin is condensed into a single round cluster. Arrowheads indicate pyknotic nuclei in which the chromatin is condensed into multiple, smaller clusters, all of which are considered to be part of a single nucleus because they are contained within a distance comparable to one nuclear diameter. Scale bars, $5 \mu \mathrm{m}$.
Because for each tissue we determined the relative amounts of BDNF measured by the ECLIA assay at two different dilutions, we applied the appropriate correction factor to make the measurements obtained at the stronger tissue concentrations comparable with the measurements obtained at the weaker, more efficient concentrations.

Recovery of an exogenous BDNF spike $(0.3 \mathrm{ng} / \mathrm{ml})$ added before homogenization was determined for both retina and SC samples. These control experiments revealed that $\sim 80 \%$ of the BDNF spike was recovered using our BDNF extraction procedure. Therefore, our measurements of BDNF may underestimate the amounts of BDNF by $20 \%$.

To extract BDNF, we diluted samples as described in detail elsewhere (Johnson et al., 1995, 1996) in 100 mM PIPES homogenization buffer, pH 7.0, containing $500 \mathrm{~mm} \mathrm{NaCl}, 2 \%$ BSA, $0.2 \%$ Triton $\mathrm{X}-100,0.1 \% \mathrm{NaN}_{3}$, and fresh protease inhibitors $(2 \mu \mathrm{g} / \mathrm{ml}$ aprotinin, 2 mM EDTA, $10 \mu \mathrm{M}$ leupeptin, $1 \mu \mathrm{M}$ pepstatin, and $200 \mu \mathrm{M}$ PMSF), and homogenized the samples using ground glass dounces. Homogenates were centrifuged at $16,000 \times g$ for $20 \mathrm{~min}$ to pellet insoluble material. Supernatants were collected and stored at $-85^{\circ} \mathrm{C}$ before BDNF ECLIA.

ECLIA. Immunoassays used an affinity-purified BDNF-specific rabbit polyclonal antibody (Yan et al., 1997) in an immunomagnetic sandwich assay with a detection limit of $\sim 500 \mathrm{fg} / \mathrm{tube}$ and a dynamic range of $\sim 10^{4}$. The assay is capable of detecting BDNF from tissue samples as small as $1 \mu \mathrm{l}$ (Johnson et al., 1995, 1996). BDNF is captured from tissue homogenate supernatants via biotinylated antibodies on streptavidincoated Dynal $2.8 \mu \mathrm{m}$ magnetic beads. Captured BDNF is then measured from electrochemiluminescence (ECL) emitted by TAG-labeled antibodies (Igen, Rockville, MD) in an Origen Analyzer (Igen). One hundred fifty microliters of ECLIA reaction mixture (12.5 $\mathrm{ng}$ of biotinylated rabbit polyclonal anti-BDNF antibody, $25 \mathrm{ng}$ of TAG-labeled rabbit polyclonal anti-BDNF antibody, and $10 \mu \mathrm{g}$ of Dynal $2.8 \mu \mathrm{m} \mathrm{M}-280$ streptavidin magnetic beads diluted in $\mathrm{Ca}^{2+}$ - and $\mathrm{Mg}^{2+}$-free Dulbecco's PBS, pH 7.2, containing 3\% BSA, $1.5 \%$ Tween 20, and $0.05 \% \mathrm{NaN}_{3}$ ) is added to $50-400 \mu \mathrm{l}$ of tissue supernatant unknowns aliquoted in $12 \times 75$ $\mathrm{mm}$ polypropylene tubes. Sample reaction mixtures are vortexed for 90 min using the Origen Analyzer carousel. The reaction is terminated by the addition of an equivalent volume $(200-550 \mu \mathrm{l})$ of Origen assay buffer per tube. ECL counts are measured sequentially from each sample using the Origen Analyzer. ECL counts from the tissue homogenate buffer (blanks) are subtracted from all values. BDNF concentrations for tissue supernatants are calculated from regression analysis of a human recombinant BDNF standard curve run in each assay.

\section{RESULTS}

Because virtually all RGCs project to the hamster SC (Linden and Esbérard, 1987), DY injected into the SC on P1 is retrogradely transported to RGC somata. It is incorporated into the RGC nuclei and produces a fluorescent signal that is robust on P4 (Fig. 1). Because, by definition, RGCs are the only neurons in the retina that have an axon projecting into the brain, they are selectively labeled by DY. Similarly, because DY remains in the nucleus for months (Keizer et al., 1983), the pyknotic nuclei of dying RGCs are readily identified because they are labeled by DY (Fig. 1). Within a defined sampling region, the number of pyknotic (condensed chromatin) DY-labeled nuclei can be expressed as a percentage of the total number of DY-labeled nuclei. Assuming that the persistence of pyknotic nuclei is relatively constant and unaffected by neurotrophin treatment, one can use this percentage as an index of the rate of RGC death. We determined the frequency of pyknotic RGCs on P4, 8 or $20 \mathrm{hr}$ after intracollicular injection of BDNF or vehicle.

\section{Intracollicularly administered BDNF reduces the rate of normal, developmental RGC death $20 \mathrm{hr}$ after injection}

The principal goal of this study was to determine whether exogenous BDNF injected into the $\mathrm{SC}$ would reduce the rate of normal, developmental RGC death, assayed by the frequency of pyknotic RGC nuclei. Twenty hours after injection, the frequency of DY-labeled pyknotic RGCs was $\sim 13$-fold higher after vehicle than after BDNF treatment (Fig. 2, groups $B$ and $A$, respectively; $p=0.014)$. The frequency of DY-labeled pyknotic RGCs was $\sim 15$-fold higher in hamsters that received DY injections with no further treatment (Fig. 2, group $C$ ) than it was in hamsters that received BDNF treatment after DY injections (Fig. 2, group $A ; p=0.021$ ). Therefore, $20 \mathrm{hr}$ after 
Figure 2. Histograms showing the frequency of pyknotic RGCs or pyknotic cells in the retinal ganglion cell layer. Below the histograms, the treatment of each group of animals is summarized. $B D N F, B S A$, and $D Y$ indicate bilateral injection of those substances into the superior colliculus. Hoechst and $H$ indicate postmortem staining of the retina with Hoechst dye. Survival indicates the number of hours between the injection of BDNF or BSA and the killing of the hamsters on $\mathrm{P} 4 ; n$ indicates the number of hamsters in each experimental group. Mean indicates the mean percentage of labeled nuclei that are pyknotic in each experimental group; the SD of this percentage is given.

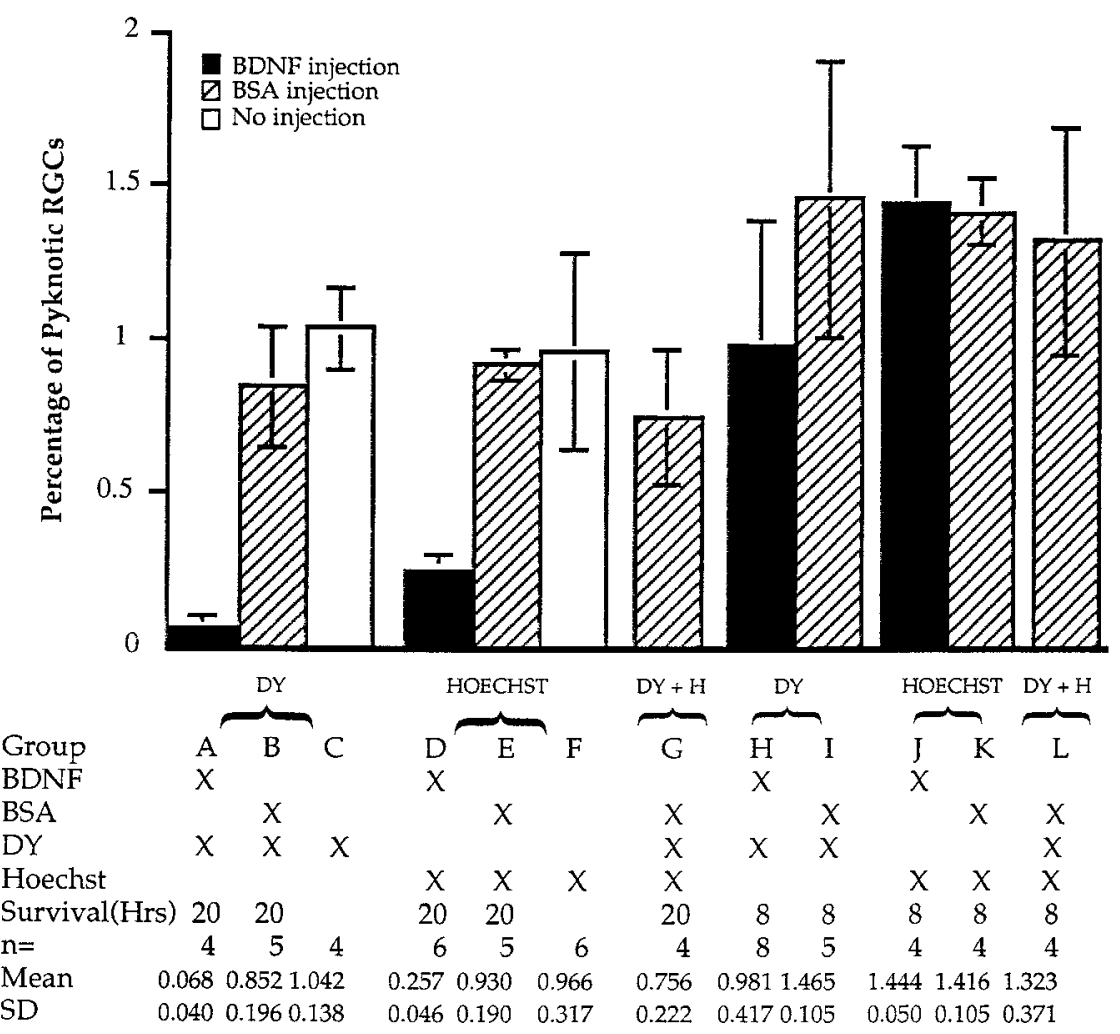

injection of $\mathrm{BDNF}$ into the $\mathrm{SC}$, there was a significant reduction in the rate of developmental RGC death.

\section{Injection procedures and DY do not affect rate of RGC death}

The injection of DY or a test agent (BDNF or vehicle) into the SC could produce a lesion in this important target of the retina, potentially causing RGC death that is reduced by BDNF treatment. Three sets of control experiments demonstrate that $20 \mathrm{hr}$ after treatment, intracollicularly administered BDNF is truly reducing normal, developmental RGC death.

\section{$D Y$ injection on P1 has no significant effect on the rate of} RGC pyknosis on $P 4$

This conclusion is based on two sets of observations. (1) BDNF or vehicle was injected intracollicularly $20 \mathrm{hr}$ before killing on P4, but the injection of DY on P1 was omitted (Fig. 2, groups $D$ and $E$, respectively). Nuclei in the RGC layer of the retina were visualized by staining retinal whole mounts with Hoechst nuclear dye. This procedure eliminates any damage to the SC because of the DY injection. The BDNF-treated group showed an approximately fourfold reduction in the rate of pyknosis in the RGC layer compared with that of the vehicle-treated group $(p=$ 0.011). The reduced magnitude of the effect determined by Hoechst staining is expected. Amacrine cells constitute about half the neurons in the RGC layer (Linden and Esbérard, 1987), and glial cells are also present in that layer. The pyknotic rate of retinal neurons that are not RGCs is unaffected by BDNF injection in the SC, because at the developmental stage of the hamsters used in our experiments, those neurons are not trophically dependent on RGCs (Beazley et al., 1987). Because the Hoechst dye stains RGCs, amacrine cells, and glial cells in the RGC layer after intracollicular BDNF injection, the pyknotic rate when all three populations of cells are pooled will be greater than that obtained from RGCs alone. Despite this, when nuclei in the RGC layer are stained with Hoechst dye to control for the possible effects of DY injection, the reduction in the rate of RGC pyknosis by BDNF is robust enough to produce a significant reduction in the frequency of pyknotic profiles when all cells in the RGC layer are pooled.

(2) In hamsters killed on P4 without any previous treatment and the retinae of which were stained with Hoechst dye as described above (Fig. 2, group $F$ ), there can be no damage to the $\mathrm{SC}$ because of DY or vehicle injections. There is no significant difference between the rate of pyknosis (revealed by Hoechst staining) in the retinae of these hamsters and the rate of pyknosis (revealed by DY labeling) in the retinae of hamsters that received a DY injection on P1 with no additional treatment (Fig. 2, group $C ; p=0.7)$. Thus, DY injection on $\mathrm{P} 1$ has no significant effect on the rate of RGC pyknosis on $\mathrm{P} 4$.

The injection procedure $20 \mathrm{hr}$ before killing has no significant effect on the rate of RGC pyknosis on P4

In hamsters killed on $\mathrm{P} 4$ without any previous treatment and the retinae of which were stained with Hoechst dye as described above (Fig. 2, group $F$ ), there is no damage to the SC because of DY or vehicle injections. There was no significant difference in the rate of pyknosis in the RGC layer between retinae from this group and the retinae from hamsters that were not treated with DY and that had retinae stained with Hoechst dye $20 \mathrm{hr}$ after vehicle injection (Fig. 2, group $E ; p=0.831$ ). Furthermore, there was no significant difference between the rate of pyknosis in hamsters that received only DY injections on P1 and in hamsters that were treated with vehicle after DY injections (Fig. 2, groups $C$ and $B$, respectively; $p=0.086$ ). 
The combined effects of the injection of DY on P1 and the injection procedure $20 \mathrm{hr}$ before killing on P4 did not have any significant effect on the rate of developmental cell death in the $R G C$ layer

In a final group of hamsters, we injected DY on P1 and vehicle 20 hr before killing on P4; in these animals, nuclei in the RGC layer of the retina were visualized by staining with Hoechst dye as described above (Fig. 2, group $G$ ). In these hamsters, we counted all of the normal and pyknotic Hoechst-stained nuclei, regardless of whether or not they were labeled with DY (i.e., in this group of hamsters, DY was treated as an additional pharmacological agent rather than as a tracer). The rate of pyknosis in the RGC layer of these animals was not significantly different from the rate of pyknosis determined by counting Hoechst-labeled nuclei in the RGC layer of hamsters that received no injections before killing on $\mathrm{P} 4$ (Fig. 2, group $F ; p=0.286$ ).

Taken together, these control experiments demonstrate that the reduced frequency of pyknotic nuclei in BDNF-treated hamsters is caused by a reduction in normal, developmental RGC death rather than by a reduction in RGC death induced by injury or toxicity associated with the experimental procedures.

\section{Intracollicularly administered BDNF does not affect the rate of normal, developmental RGC death at $8 \mathrm{hr}$ after injection}

Because neurotrophins cause trk receptor phosphorylation within minutes (Segal et al., 1996) and trk-derived signals could be retrogradely transported over the distance from the SC to the retina within $2 \mathrm{hr}$, we also examined the effects of BDNF treatment $8 \mathrm{hr}$ after intracollicular injection. Eight hours after an injection of BDNF or vehicle on P4, hamsters injected with DY on P1 did not differ significantly with respect to the frequency of pyknotic RGCs (Fig. 2, groups $H$ and $I$, respectively; $p=0.107$ ). Furthermore, the frequency of DY-labeled pyknotic RGCs was not significantly different between BDNF-treated hamsters and hamsters that received DY injections with no further treatment (Fig. 2, groups $H$ and $C$, respectively; $p=0.706$ ). Thus, intracollicularly injected BDNF does not significantly alter the rate of normal, developmental RGC death $8 \mathrm{hr}$ after it is administered.

As for hamsters that survived BDNF or vehicle treatment for $20 \mathrm{hr}$, we undertook control experiments to determine whether the injection of DY or a test agent might produce lesion-induced RGC death that could confound our analysis of the effects of BDNF on normal, developmental RGC death $8 \mathrm{hr}$ after treatment.

(1) BDNF or vehicle were injected intracollicularly $8 \mathrm{hr}$ before killing on P4, but the injection of DY on P1 was omitted (Fig. 2, groups $J$ and $K$, respectively). There was no significant difference between the two groups with respect to the rate of pyknosis in the RGC layer revealed by staining with Hoechst dye ( $p=0.387)$. This datum suggests that the injection of DY on P1 did not significantly affect the comparison of the effects of injecting BDNF or vehicle $8 \mathrm{hr}$ after administration.

(2) In Hoechst-stained retinae of hamsters that were not injected previously with DY but that were treated with vehicle $8 \mathrm{hr}$ before killing on $\mathrm{P} 4$ (Fig. 2, group $K$ ), the frequency of pyknotic figures in the RGC layer was $\sim 50 \%$ greater than that in the RGC layer of retinae from untreated hamsters stained with Hoechst dye (Fig. 2, group $F ; p=0.033$ ). However, there was no significant difference between the rate of pyknosis in hamsters that received only DY injections on P1 and hamsters that were treated with vehicle after DY injections (Fig. 2, groups $C$ and $I$, respectively; $p=0.142$ ). The results of our third control experiment (next paragraph) suggest that the discrepant results obtained with Hoechst dye are an aberration and that the effect of the injection procedure $8 \mathrm{hr}$ before killing is not significant.

(3) In a final group of hamsters, we injected DY on P1 and vehicle $8 \mathrm{hr}$ before killing on $\mathrm{P} 4$; in these animals, nuclei in the RGC layer of the retinae were visualized by staining with Hoechst dye as described above (Fig. 2, group $L$ ). In these hamsters, we counted all the normal and pyknotic Hoechst dye-stained nuclei, regardless of whether or not they were labeled with DY. The rate of pyknosis in the RGC layer of these animals was not significantly different from the rate of pyknosis determined by counting Hoechst dye-labeled nuclei in the RGC layer of hamsters that received no injections before killing on P4 (Fig. 2, group $F ; p=0.201)$. Thus, the combined effects of the injection of DY on P1 and the injection procedure $8 \mathrm{hr}$ before killing on P4 did not have any significant effect on the rate of cell death in the RGC layer.

\section{Tests for regional variations in the rate of naturally occurring RGC death}

In hamsters that were either untreated before killing (and the retinae of which were Hoechst-stained postmortem; Fig. 2, group $F$ ) or treated only with DY on P1 (Fig. 2, group $C$ ), we tested for significant differences among the superior, inferior, temporal, and nasal sampling regions, with respect to the rate of naturally occurring pyknosis in the RGC layer. No significant differences were found using either technique (Fig. 3).

\section{Measurements of exogenous BDNF in the SC and retina after injection}

On P4, we measured the amount of BDNF protein in the SC and retinae of hamsters that had received unilateral injections of BDNF into the SC $12 \mathrm{hr}$ previously, late on P3. (A $12 \mathrm{hr}$ interval after injection was used because preliminary experiments had indicated that the first hint of elevated retinal BDNF levels occurs at $6 \mathrm{hr}$ after injection and that retinal BDNF levels peak $\sim 12 \mathrm{hr}$ after injection.) For controls, we also measured the amount of $\mathrm{BDNF}$ in the SC of hamsters that were killed immediately after receiving unilateral injections of BDNF into the SC " $0 \mathrm{hr}$ " survival) or $12 \mathrm{hr}$ after receiving unilateral injections of vehicle into the SC.

Our ECLIA measurements on the SC (Fig. 4; Table 1) indicate that in normal hamsters, the wet tissue concentration of BDNF is $\sim 43 \mathrm{pg} / \mathrm{mg}$ and that the total amount of BDNF in each SC (one side) is $\sim 152 \mathrm{pg}$. In hamsters killed immediately after unilateral injections of BDNF, the average amount of BDNF in the injected $\mathrm{SC}$ is $\sim 79 \mathrm{ng}(\sim 520$ times the normal amount), whereas the noninjected SC contains $\sim 1.2 \mathrm{ng}$ of BDNF (approximately eight times the normal amount and $\sim 1.5 \%$ of the total amount injected). In hamsters killed $12 \mathrm{hr}$ after unilateral injections of BDNF, the average amount of BDNF in the injected SC is $15.31 \pm 6.08$ ng $(\sim 101$ times the normal amount), whereas the noninjected SC contains an average of $2.15 \pm 1.36 \mathrm{ng}$ of BDNF ( $\sim 14$ times the normal amount). Therefore, $\sim 19 \%$ of the BDNF that was successfully injected into the SC was still there $12 \mathrm{hr}$ later. In hamsters killed $12 \mathrm{hr}$ after unilateral injections of vehicle, the average amounts of BDNF in the injected and noninjected SC are 164 and $149 \mathrm{pg}$, respectively; these amounts correspond to 108 and $98 \%$ of the average normal values, respectively, and are within the normal range of variation. Therefore, the injection procedure does not cause any significant changes in BDNF levels in the SC. 

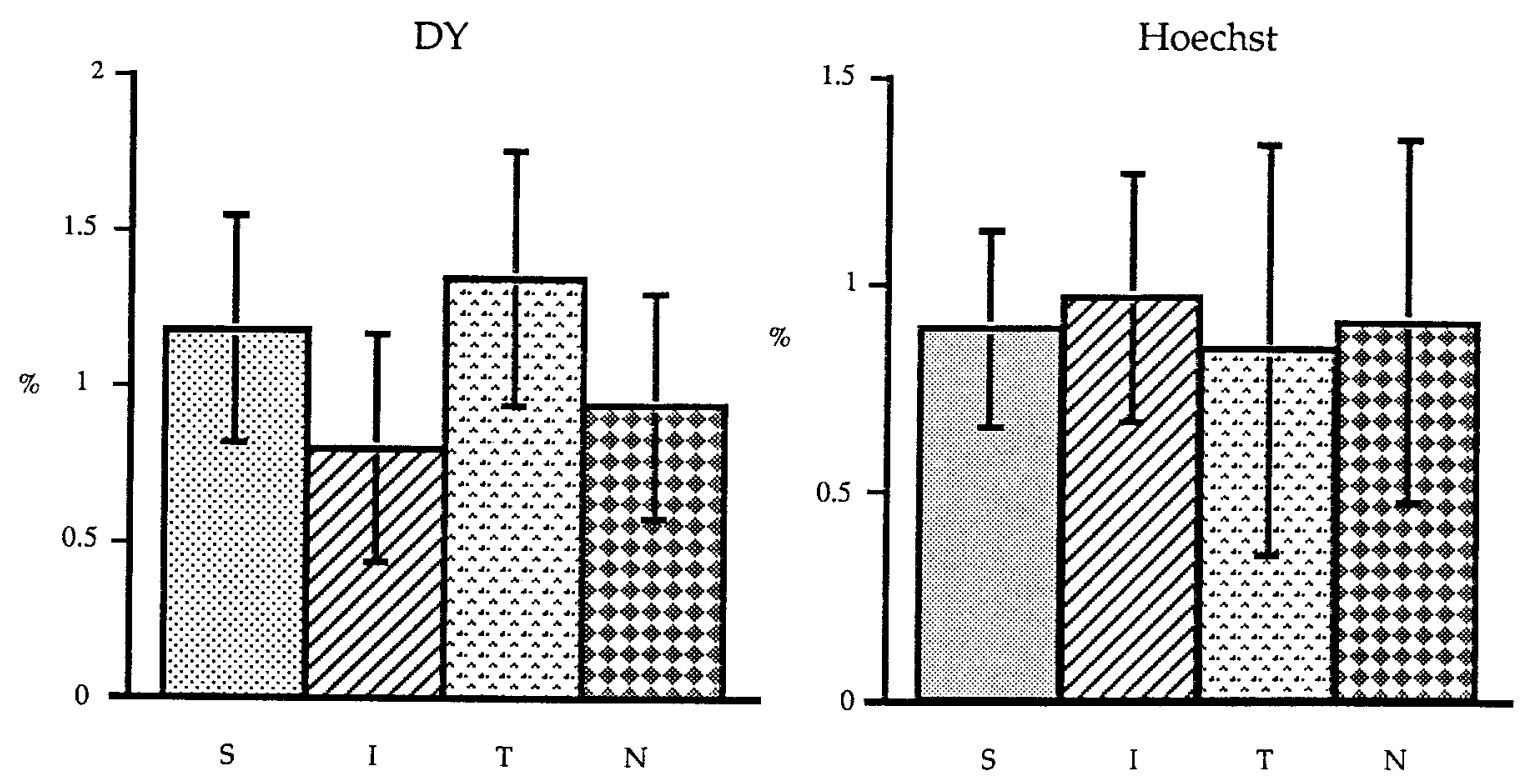

Figure 3. Histograms showing the frequency of pyknotic RGCs or pyknotic cells in the retinal ganglion cell layer in each of the four sampling regions of untreated hamsters. Left, Percentage of DY-labeled RGC nuclei that are pyknotic. Right, Percentage of Hoechst-labeled nuclei in the retinal ganglion cell layer that are pyknotic. $S$, Superior retina; $I$, inferior retina; $T$, temporal retina; $N$, nasal retina.
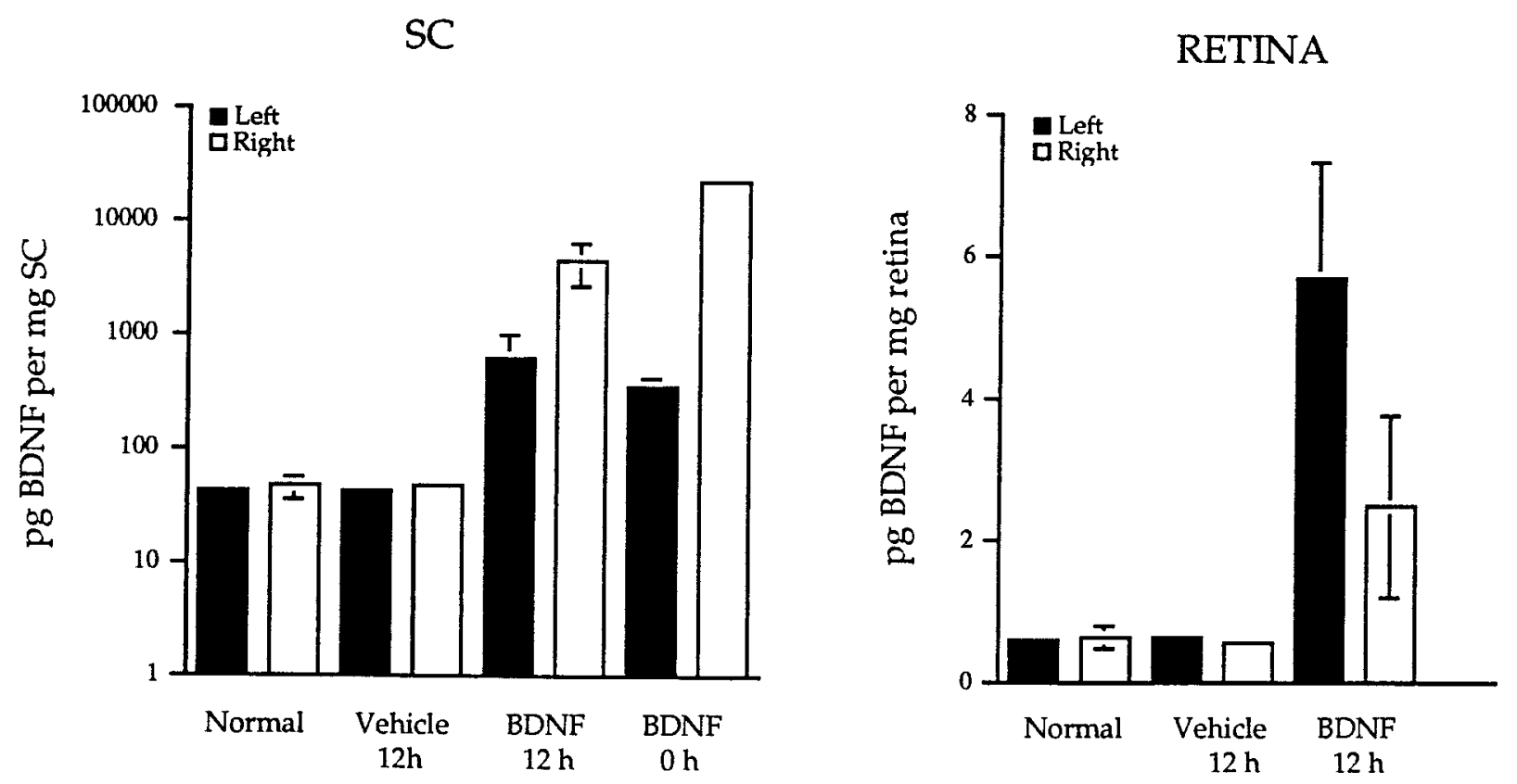

Figure 4. Histograms showing tissue concentrations of BDNF in normal hamsters and in experimental hamsters $12 \mathrm{hr}$ after injection of vehicle and 0 or $12 \mathrm{hr}$ after injection of BDNF. In experimental animals, the right SC was injected. Note that a logarithmic scale was used for the $y$-axis of the SC histograms (left), whereas a linear scale was used for the $y$-axis of the retinal histograms (right).

Our ECLIA measurements on the retina (Fig. 4; Table 2) indicate that in normal hamsters on $\mathrm{P} 4$, the average retinal tissue concentration of BDNF is $0.61 \mathrm{pg} / \mathrm{mg}$ and the total amount of $\mathrm{BDNF}$ in the retina is $2.44 \mathrm{pg}$. In hamsters killed $12 \mathrm{hr}$ after unilateral injections of BDNF, the average amount of BDNF in the contralateral eye is $22.58 \pm 6.52 \mathrm{pg}$ (approximately nine times the normal amount), whereas the average amount of BDNF in the ipsilateral eye is $9.87 \pm 5.13 \mathrm{pg}$ (approximately four times the normal amount). Therefore, $12 \mathrm{hr}$ after the injection, the amount of exogenous BDNF in the retina contralateral to the injected SC
(20.14 pg) is $0.025 \%$ of the amount of exogenous BDNF in the SC at $0 \mathrm{hr}$ after injection and $0.132 \%$ of the amount of exogenous BDNF remaining in the SC $12 \mathrm{hr}$ after injection. The elevated BDNF levels in the ipsilateral retina are probably attributable principally to retrograde transport of BDNF that spilled into the uninjected SC and was taken up by RGCs that make a crossed retino-SC projection. In both retinae, retrograde transport of BDNF by RGCs that make uncrossed projections probably contributes little to overall BDNF levels because contralaterally projecting RGCs vastly outnumber ipsilaterally projecting RGCs at 


\begin{tabular}{|c|c|c|c|c|}
\hline Case/side & Type of injection & $\mathrm{pg} \mathrm{BDNF/mg} \mathrm{SC}$ & Total BDNF/SC (pg) & Exogenous BDNF (ng) \\
\hline \multicolumn{5}{|l|}{ No injection } \\
\hline C 1-L & None & 46.04 & 164 & \\
\hline C 1-R & None & 44.38 & 158 & \\
\hline C 2-L & None & 39.36 & 141 & \\
\hline C 2-R & None & 45.22 & 161 & \\
\hline C 3-L & None & 37.68 & 135 & \\
\hline C 3-R & None & 35.54 & 127 & \\
\hline C 4-L & None & 46.73 & 167 & \\
\hline C 4-R & None & 62.10 & 222 & \\
\hline C 5-L & None & 32.92 & 118 & \\
\hline C 5-R & None & 38.57 & 138 & \\
\hline C 6-L & None & 40.10 & 143 & \\
\hline C 6-R & None & 42.43 & 151 & \\
\hline Mean $\mathrm{L} \pm \mathrm{SD}$ & & $40.47 \pm 5.22$ & $144.67 \pm 18.40$ & \\
\hline Mean $\mathrm{R} \pm \mathrm{SD}$ & & $44.71 \pm 9.27$ & $159.50 \pm 33.17$ & \\
\hline \multicolumn{5}{|c|}{ Vehicle injection $(12 \mathrm{hr})$} \\
\hline BSA 1-L & None & 43.28 & 155 & \\
\hline BSA $1-R$ & BSA & 43.29 & 155 & \\
\hline BSA 2-L & None & 41.38 & 148 & \\
\hline BSA 2-R & BSA & 46.56 & 166 & \\
\hline BSA 3-L & None & 40.52 & 145 & \\
\hline BSA 3-R & BSA & 47.64 & 170 & \\
\hline Mean $\mathrm{L} \pm \mathrm{SD}$ & & $41.73 \pm 1.41$ & $149 \pm 5$ & \\
\hline Mean $\mathrm{R} \pm \mathrm{SD}$ & & $45.83 \pm 2.26$ & $164 \pm 8$ & \\
\hline \multicolumn{5}{|c|}{ BDNF injection (12 hr) } \\
\hline BDNF 1-L & None & 352 & 1257 & 1.10 \\
\hline BDNF 1-R & BDNF & 4104 & 14651 & 14.50 \\
\hline BDNF 2-L & None & 548 & 1956 & 1.80 \\
\hline BDNF 2-R & BDNF & 4954 & 17686 & 17.53 \\
\hline BDNF 3-L & None & 1007 & 3595 & 3.44 \\
\hline BDNF 3-R & BDNF & 5719 & 20417 & 20.26 \\
\hline BDNF 4-L & None & 1022 & 3649 & 3.50 \\
\hline BDNF 4-R & BDNF & 4253 & 15183 & 15.03 \\
\hline BDNF 5-L & None & 922 & 3292 & 3.14 \\
\hline BDNF 5-R & BDNF & 2592 & 9253 & 9.10 \\
\hline BDNF 6-L & None & 217 & 775 & 0.62 \\
\hline BDNF 6-R & BDNF & 1749 & 6244 & 6.09 \\
\hline BDNF 7-L & None & 145 & 518 & 0.37 \\
\hline BDNF 7-R & BDNF & 6649 & 23737 & 23.58 \\
\hline Mean $\mathrm{L} \pm \mathrm{SD}$ & & $602 \pm 380$ & $2149 \pm 1356$ & $2.00 \pm 1.36$ \\
\hline Mean $\mathrm{R} \pm \mathrm{SD}$ & & $4289 \pm 1704$ & $15310 \pm 6084$ & $15.16 \pm 6.08$ \\
\hline \multicolumn{5}{|c|}{ BDNF injection $(0 \mathrm{hr})$} \\
\hline BDNF 8-L & None & 390 & 1392 & 1.24 \\
\hline BDNF 8-R & BDNF & 22399 & 79964 & 79.81 \\
\hline BDNF 9-L & None & 281 & 1003 & 0.85 \\
\hline BDNF 9-R & BDNF & 21850 & 78005 & 77.85 \\
\hline Mean $\mathrm{L} \pm \mathrm{SD}$ & & $336 \pm 77$ & $1198 \pm 275$ & $1.04 \pm 0.28$ \\
\hline Mean $\mathrm{R} \pm \mathrm{SD}$ & & $22124 \pm 388$ & $78984 \pm 1385$ & $78.83 \pm 1.38$ \\
\hline
\end{tabular}

Measurements of total BDNF in one SC assume that all SC are of average weight $(3.57 \mathrm{mg})$.

all developmental stages (Insausti et al., 1984). In hamsters killed $12 \mathrm{hr}$ after unilateral injections of vehicle, the average amounts of $\mathrm{BDNF}$ in the retinae contralateral and ipsilateral to the injected SC are 2.47 and $2.23 \mathrm{pg}$, respectively; these amounts correspond to 101 and $91 \%$ of the average normal values, respectively, and are within the normal range of variation. Therefore, the injection procedure does not cause any significant changes in BDNF levels in the retina.
When ECLIA measurements of BDNF are normalized by tissue weight, large differences between the retina and SC are observed. Measurements of total soluble protein are nearly identical in both of these tissues $(0.075 \mathrm{mg}$ of protein $/ \mathrm{mg}$ of tissue in the $\mathrm{SC}$ and $0.070 \mathrm{mg} / \mathrm{mg}$ in the retina). Therefore, BDNF measurements normalized by tissue soluble protein yield similar large differences between the retina and the SC.

There are considerable interlitter variations in the weight of the 
Table 2. ECLIA measurements on retinal tissue

\begin{tabular}{lll} 
Case/side & pg BDNF/mg retina & $\begin{array}{l}\text { Average BDNF/ } \\
\text { retina }(\mathrm{pg})\end{array}$ \\
\hline No injection & & \\
C 1,2,3 L & 0.66 & 2.63 \\
C 1,2,3 R & 0.73 & 2.91 \\
C 4,5,6 L & 0.54 & 2.15 \\
C 4,5,6 R & 0.52 & 2.07 \\
Mean L \pm SD & $0.6 \pm 0.08$ & $2.39 \pm 0.34$ \\
Mean R \pm SD & $0.62 \pm 0.15$ & $2.49 \pm 0.59$ \\
Vehicle injection & & \\
(12 hr survival) & & \\
BSA 1,2,3 L & 0.62 & 2.47 \\
BSA 1,2,3 R & 0.56 & 2.23 \\
BDNF injection & & \\
$(12$ hr survival) & & 15.08 \\
BDNF 1,2 L & 3.78 & 4.12 \\
BDNF 1,2 R & 1.03 & 26.85 \\
BDNF 3,4 L & 6.73 & 13.93 \\
BDNF 3,4 R & 3.49 & 25.82 \\
BDNF 5,6,7 L & 6.47 & 11.61 \\
BDNF 5,6,7 R & 2.91 & $22.58 \pm 6.52$ \\
Mean L \pm SD & $5.66 \pm 1.63$ & $9.87 \pm 5.13$ \\
Mean R \pm SD & $2.48 \pm 1.28$ & \\
& &
\end{tabular}

Left $(L)$ eye is contralateral to the injected SC; right $(R)$ eye is ipsilateral to the injected SC. Measurements of total BDNF in one retina assume that all retinae are of average weight $(3.99 \mathrm{mg})$.

retinae on $\mathrm{P} 4$ (data not shown). The retinae of animals from the same litter have similar weights, regardless of whether the animals were normal, injected with BDNF, or injected with vehicle, whereas animals from different litters can have dramatically different retinal weights even when they were subjected to similar treatments. These data suggest that treatment does not significantly affect retinal weight. Because of the interlitter weight variations, when we compared the total amount of BDNF in the retinae of animals from different treatment groups, we multiplied the tissue concentration of BDNF by the average retinal weight for all of the animals used in our ECLIA measurements.

We also conducted a preliminary analysis of BDNF levels in the injected SC on P5, P6, P7, and P10 (2, 3, 4, and 7 d, respectively, after the injection of BDNF on P3). Our data (not shown) indicate that, by $\mathrm{P} 5$, the tissue concentration of BDNF in the injected SC falls to approximately eight times endogenous levels and that, at later time points, the tissue concentration of BDNF is 1.5-2.5 times endogenous levels. Therefore, the exogenous BDNF appears to be rapidly cleared from the injection site. By P5, retinal BDNF levels are not significantly different from normal.

\section{BDNF is transported to the retina by retrograde axonal transport}

We considered the possibility that BDNF reaches the retina and exerts its effects either by being transported in the blood or by diffusion through the extracellular space. To control for these possibilities, we measured the tissue concentration of BDNF protein in the olfactory bulb $12 \mathrm{hr}$ after intracollicular injection of BDNF $(n=3)$ or vehicle $(n=3)$. Because the olfactory bulb neither receives axons from nor sends axons to the SC, any increase in BDNF levels in this structure after intracollicular BDNF injections would have to be attributable to transport through the blood, diffusion through the extracellular space, or transneuronal transport over multiple synapses. The mean BDNF concentration was $9.8 \mathrm{pg} / \mathrm{mg}$ of tissue in the bulbs of BDNFtreated hamsters and $9.1 \mathrm{pg} / \mathrm{mg}$ in the bulbs of vehicle-treated hamsters (data not shown). The absence of a significant difference in BDNF concentration between the two groups $(p=0.2752)$ indicates that none of the alternative pathways just listed carries significant amounts of BDNF from the SC to other brain regions. The lack of effect of intraocularly injected BDNF on the rate of developmental RGC death (Cui and Harvey, 1994) further supports this conclusion. Therefore, the BDNF we detected in the retina arrives there by retrograde axonal transport after internalization at retinocollicular axon terminals, probably by a receptormediated mechanism (von Bartheld et al., 1996).

\section{DISCUSSION}

We injected BDNF into the SC of neonatal hamsters. At the age when the rate of developmental RGC death is greatest, BDNF produces, $20 \mathrm{hr}$ after injection, a 13-15-fold reduction in the rate of RGC pyknosis. This effect occurs after intracollicular BDNF is increased $\sim 100$-fold over endogenous concentrations and after retinal BDNF is increased approximately ninefold. BDNF has no significant effect on RGC pyknosis $8 \mathrm{hr}$ after injection into the SC.

\section{Effects of target-derived BDNF on retinal neurons}

This is the first demonstration of an effect of excess, targetderived neurotrophin on developmental RGC death. Our data demonstrate a pronounced reduction in the rate of RGC pyknosis as a consequence of elevated BDNF levels in the SC, to which virtually all RGCs project. Because the developmental death of RGCs is by a pyknotic process (Rehen and Linden, 1994), the reduced frequency of pyknosis indicates a reduced rate of developmental RGC death.

One question not addressed by our experiments is whether the effect of intracollicularly injected BDNF on RGC death is direct, indirect, or both. The presence of trkB receptors on RGCs in vivo (Ernfors et al., 1992; Koide et al., 1995; Rickman and Brecha, 1995; Ugolini et al., 1995) and the survival-promoting effect of BDNF on dissociated RGCs in vitro (Johnson et al., 1986; Thanos et al., 1989; Castillo et al., 1994) suggest a direct action. Our data on the dynamics of retrograde transport of exogenous BDNF by RGCs and on the time course of the BDNF-induced reduction in RGC pyknotic rate are consistent with (but do not prove) a direct action of BDNF on RGCs. Although retinal BDNF levels begin to increase $\sim 6 \mathrm{hr}$ after treatment (Ma et al., unpublished observations), there is no significant change in the rate of RGC pyknosis until some time between 8 and $20 \mathrm{hr}$ after treatment. Such a delayed effect is expected in the case of a direct action of BDNF. Cells undergoing developmental death become committed to die before pyknosis is apparent (Deckwerth and Johnson, 1993; Johnson and Deckwerth, 1993; Earnshaw, 1995). Therefore, several hours are required between the arrival of retrogradely transported survival factors in their target somata and a reduction in pyknotic rate. Intraocularly injected BDNF acts directly, and with a delay, to reduce the developmental death of chick isthmo-optic neurons (Primi and Clarke, 1996). BDNF, even if it acts directly, may not be the survival-promoting signal that is transmitted to the retina. Intracellular messengers [e.g., phosphorylated trkB receptors (Johanson et al., 1995; Bhattacharyya et al., 1997)] that are activated when BDNF binds to its receptors on RGC axon terminals might be cotransported to the retina with BDNF. Our results are also consistent with indirect actions of BDNF. Elevated levels of intracollicular BDNF might reduce RGC pyknosis 
by increasing the expression of other factors by SC cells or of the receptors for those factors by RGCs (Wyatt and Davies, 1993). The reduction in programmed RGC death by target-derived BDNF contrasts with the apparent lack of effect of intraocularly injected BDNF (Cui and Harvey, 1994). This datum suggests that in rodents, during the developmental stage we examined, BDNF does not promote RGC survival by the autocrine or paracrine loops that may act in Xenopus (Cohen-Cory et al., 1996) and chick (Herzog and von Bartheld, 1997).

\section{Technical considerations}

Our control experiments exclude the possibility that BDNF treatment is reducing RGC death caused by a lesion of SC resulting from injection of DY, BDNF, or vehicle rather than normal, developmental RGC death. Previous studies (Cui and Harvey, 1994) using DY as a tracer did not control for the possibility that it could cause significant RGC death.

We took care to avoid sampling biases. One cannot exclude a priori that there are regional variations in RGC pyknotic rate. Therefore, we probed corresponding parts of the retina in all cases and specifically searched for such regional variations. None were found. No controls for regional variations in RGC pyknotic rate were made in a previous study of the effects of intraocularly injected agents on developmental RGC death in rats (Cui and Harvey, 1994). Furthermore, we counted all normal and pyknotic nuclei throughout the thickness of the RGC layer. In the previous study (Cui and Harvey, 1994), only nuclei visible in random planes of focus were counted. Pyknotic nuclei are often smaller than normal nuclei, so counts of these elements within a restricted optical "slice" through the RGC layer can be compared only after correcting for their different diameter spectra. Because no correction was made in the previous study, the calculated pyknotic frequencies may be inaccurate.

We have not compared the number of "live" RGCs in the retinae of BDNF-treated and control hamsters. The rate of naturally occurring RGC loss is $\sim 1100 / \mathrm{hr}$ (Sefton and Lam, 1984; Crespo et al., 1985), and the total number of RGCs on P4 is on the order of $10^{5}$ (Sefton and Lam, 1984; Crespo et al., 1985; Tay et al., 1986). Because of the delayed effect of BDNF in reducing RGC death, one would expect that the retinae of treated hamsters at $20 \mathrm{hr}$ after injection would have only a few thousand RGCs more than control hamsters have, a difference too small to detect given the interanimal variability of both total RGC number and the rate of RGC death. Although significant effects of BDNF injection on the number of surviving RGCs would be expected at longer intervals after injection, the rapid clearance of exogenous $\mathrm{BDNF}$ from the SC would necessitate repeated injections or chronic infusion in order to observe a long-term effect. This is not feasible in the neonatal rodent brain.

\section{Do neurotrophins regulate the normal, developmental death of RGCs and other CNS neurons?}

We have demonstrated a pharmacological effect of target-derived BDNF on developmental RGC death. Conclusive demonstration of the action of physiological concentrations of BDNF remains elusive. Dramatic effects of BDNF and NT4 knock-outs on the retina have not been reported (Ernfors et al., 1994; Jones et al., 1994; Conover et al., 1995; Liu et al., 1995), and knock-outs of BDNF alone do not affect the number of RGCs (Cellerino et al., 1997). However, because multiple trophic factors promote RGC survival in vitro (Meyer-Franke et al., 1995), it is possible that when BDNF or NT4 are knocked out individually or together, other factors may compensate for their absence. Because of the extensive overlap in signaling pathways used by the receptors for different neurotrophins and other factors, the compensating factors may not act at the same receptor as the knocked-out factor (Heumann, 1994; Ghosh and Greenberg, 1995; Tolkovsky, 1997). In this regard, it is interesting that there are multiple factors that reduce the developmental death of motoneurons (Oppenheim et al., 1993), but knock-outs of single factors do not have profound effects on motoneuron survival. Additional regulatory mechanisms may also act in knock-out mice (Johnson and Oppenheim, 1994). Thus, in vivo treatment of developing CNS neurons with exogenous neurotrophins may reveal functions masked by the knock-out paradigm. By analogy with the effects of exogenous factors on motoneurons, BDNF may be only one of several factors that promote RGC survival in vivo.

Perhaps the divergent results concerning the role of neurotrophins as CNS survival factors (see the introductory remarks) are best reconciled by considering the relative complexities of central and peripheral neural connections. The afferents and targets of individual peripheral neurons are generally homogeneous populations, whereas those of individual central neurons are generally heterogeneous. Therefore, a population of peripheral neurons may be trophically dependent on only one or a few factors, whereas a population of central neurons may be trophically dependent on a complex mix of factors (perhaps members of different families), no one of which is necessary for survival and no one of which sustains the survival of the entire population, even when present in excess. Two observations support this hypothesis. (1) We know of no instance in which pharmacological treatment with a single trophic factor or a mix of factors promotes the survival of an entire population of immature CNS neurons, some of which normally die during development. (2) Although multiple factors are individually effective in reducing the developmental death of chick motoneurons, a crude muscle extract, probably containing a complex mix of factors, is the most potent agent in blocking motoneuron death (Oppenheim et al., 1993). The dependence of chick motoneurons (and other CNS neurons) on multiple factors may explain why, in vivo, application of many different exogenous factors can increase the survival of a particular population of neurons, but the deletion of a single factor (in transgenic mice) generally has no effect.

Exogenous BDNF, applied systemically or intratectally in chicks, seems not to affect the pyknotic rate or total number of RGCs over the interval E6-E16 (Cellerino et al., 1995; Drum et al., 1996). These data may reflect a true species difference between chicks and hamsters (D. O. Frost, Y.-T. Ma, T. Hsieh, M. E. Forbes, and J. E. Johnson, unpublished observations).

The rapid decrease in retinal and collicular BDNF levels after intracollicular injection in hamsters suggests that (1) exogenous BDNF (and probably also endogenous, secreted BDNF) is available only briefly and (2) BDNF signaling is rapid and time limited. This emphasizes the importance of the interval after treatment in assessing the effects of exogenous survival factors. It remains unknown whether chronically elevated BDNF levels in the SC would permanently stabilize a supernormal number of RGCs. We are investigating this by comparing the number of RGCs in normal mice and transgenic mice that overexpress BDNF. 


\section{REFERENCES}

Alcántara S, Frisén J, del Rio JA, Soriano E, Barbacid M, Silos-Santiago I (1997) TrkB signaling is required for postnatal survival of CNS neurons and protects hippocampal and motor neurons from axotomyinduced cell death. J Neurosci 17:3623-3633.

Allendoerfer KL, Cabelli RJ, Escandon E, Kaplan DR, Nikolics K, Shatz CJ (1994) Regulation of neurotrophin receptors during the maturation of the mammalian visual system. J Neurosci 14:1795-1811.

Alonso-Vanegas MA, Sadikot AF, Causing C, Miller F (1996) Characterization of dopaminergic midbrain neurons in a DBH:BDNF transgenic mouse. Soc Neurosci Abstr 22:41.

Beazley LD, Perry VH, Baker B, Darby JE (1987) An investigation into the role of ganglion cells in the regulation of division and death of other retinal cells. Dev Brain Res 33:169-184.

Bhattacharyya A, Watson F, Bradlee T, Pomeroy S, Stiles C, Segal R (1997) Trk receptors function as rapid retrograde signal carriers in the adult nervous system. J Neurosci 17:7007-7016.

Blackburn GF, Shah HP, Kenten JH, Leland J, Kamin RA, Link J, Peterman J, Powell MJ, Shah A, Talley DB, Tyagi SK, Wilkins E, Wu T-G, Massey RJ (1991) Electrochemiluminescence detection for development of immunoassays and DNA probe assays for clinical diagnostics. Clin Chem 37:1534-1539.

Carmingnoto G, Maffei L, Candeo P, Canella R, Comelli C (1989) Effect of NGF on the survival of rat retinal ganglion cells following optic nerve section. J Neurosci 9:1263-1272.

Castillo Jr B, Cerro M, Breakefield XO, Frim DM, Barnstable CJ, Dean DO, Bohn MC (1994) Retinal ganglion cell survival is promoted by genetically modified astrocytes designed to secrete brain-derived neurotrophic factor (BDNF). Brain Res 647:30-36.

Cellerino A, Strohmaier C, Barde Y-A (1995) Brain-derived neurotrophic factor and the developing chick retina. In: Life and death in the nervous system (Ibanez CF, ed), pp 131-139. Oxford: Elsevier.

Cellerino A, Carroll P, Thoenen H, Barde Y-A (1997) Reduced size of retinal ganglion cell axons and hypomyelination in mice lacking brainderived neurotrophic factor. Mol Cell Neurosci 9:397-408.

Cohen A, Bray GM, Aguayo AJ (1994) Neurotrophin-4/5 (NT-4/5) increase adult rat retinal ganglion cell survival and neurite outgrowth in vitro. J Neurobiol 25:953-959.

Cohen-Cory S, Fraser SE (1994) BDNF in the development of the visual system of Xenopus. Neuron 12:747-761.

Cohen-Cory S, Escandon E, Fraser SE (1996) The cellular patterns of BDNF and trkB expression suggest multiple roles for BDNF during Xenopus visual system development. Dev Biol 179:102-115.

Conover JC, Erickson JT, Katz DM, Bianchi LM, Poueymirou WT, McClain J, Pan L, Helgren M, Ip NY, Boland P, Friedman B, Wiegand S, Vejsada R, Kato AC, DeChiara TM, Yancopoulos GD (1995) Neuronal deficits, not involving motor neurons, in mice lacking BDNF and/or NT4. Nature 375:235-238.

Cowan WM, Fawcett JW, O'Leary DDM, Stanfield BB (1984) Regressive events in neurogenesis. Science 225:1258-1265.

Crespo D, O'Leary DDM, Cowan WM (1985) Changes in the numbers of optic nerve fibers during late prenatal and postnatal development in the albino rat. Dev Brain Res 19:129-134.

Cui Q, Harvey AR (1994) NT-4/5 reduces naturally occurring retinal ganglion cell death in neonatal rats. NeuroReport 5:1882-1884.

Cui Q, Harvey AR (1995) At least two mechanisms are involved in the death of retinal ganglion cells following target ablation in neonatal rats. J Neurosci 15:8143-8155.

Deckwerth TL, Johnson Jr EM (1993) Temporal analysis of events associated with programmed cell death (apoptosis) of sympathetic neurons deprived of nerve growth factor. J Cell Biol 123:1207-1222.

DiStefano PS, Friedman B, Radziejewski C, Alexander C, Boland P, Schick CM, Lindsay RM, Wiegand SJ (1992) The neurotrophins BDNF, NT-3, and NGF display distinct patterns of retrograde axonal transport in peripheral and central neurons. Neuron 8:983-993.

Drum K, Forbes ME, Wang SW, Johnson JE (1996) Treatment with BDNF does not prevent normal chick retinal ganglion cell death in ovo. Soc Neurosci Abstr 22:998.

Earnshaw WC (1995) Nuclear changes in apoptosis. Curr Opin Neurobiol 7:337-343.

Ernfors P, Lee K-F, Jaenisch R (1994) Mice lacking brain-derived neurotrophic factor develop with sensory deficits. Nature 368:147-150.

Ernfors P, Merlio J-P, Persson H (1992) Cells expressing mRNA for neurotrophins and their receptors during embryonic rat development. Eur J Neurosci 4:1140-1158.
Escandon E, Soppet D, Rosenthal A, Mendoza-Ramirez J-L, Szonyi E, Burton LE, Henderson CE, Parada LF, Nikolics K (1994) Regulation of neurotrophin receptor expression during embryonic and postnatal development. J Neurosci 14:2054-2068.

Fournier AE, Beer J, Arregui CO, Essagian C, Aguayo AJ, McKerracher L (1997) Brain-derived neurotrophic factor modulates GAP-43 but not Ta1 expression in injured retinal ganglion cells of adult rats. J Neurosci Res 47:561-572.

Frade JM, Bovolenta P, Martinez-Morales JR, Arribas A, Barbas JA, Rodriguez-Tébar A (1997) Control of early cell death by BDNF in the chick retina. Development 124:3313-3320.

Garner AS, Menegay HJ, Boeshore KL, Xie X-Y, Voci JM, Johnson JE, Large TH (1996) Expression of trkB receptor isoforms in the developing avian visual system. J Neurosci 16:1740-1752.

Ghosh A, Greenberg ME (1995) Distinct roles of bFGF and NT-3 in the regulation of cortical neurogenesis. Neuron 15:89-103.

Hallböök F, Bäckström A, Kullander K, Ebendal T, Carri NG (1996) Expression of neurotrophins and Trk receptors in the avian retina. J Comp Neurol 364:664-676.

Hefti F (1986) Nerve growth factor promotes survival of septal cholinergic neurons after fimbrial transections. J Neurosci 6:2155-2162.

Herzog K-H, von Bartheld CS (1997) Contributions of the optic tectum and the retina as sources of BDNF for retinal ganglion cells in the chick embryo. Soc Neurosci Abstr 23:2244.

Heumann R (1994) Neurotrophin signalling. Curr Biol 4:668-679.

Hofer M, Pagluisi SR, Hohn A, Liebrock J, Barde Y-A (1990) Regional distribution of brain-derived neurotrophic factor mRNA in the adult mouse brain. EMBO J 9:2459-2464.

Insausti R, Blakemore C, Cowan WM (1984) Ganglion cell death during development of ipsilateral retino-collicular projection in golden hamster. Nature 308:362-365.

Jelsma TN, Friedman HH, Berkelaar M, Bray GM, Aguayo AJ (1993) Different forms of the neurotrophin receptor trkB MRNA predominate in rat retina and optic nerve. J Neurobiol 24:1207-1214.

Johanson SO, Crouch MF, Hendry IA (1995) Retrograde axonal transport of signal transduction proteins in rat sciatic nerve. Brain Res 690:55-63.

Johnson Jr EM, Deckwerth TL (1993) Molecular mechanisms of developmental neuronal death. Annu Rev Neurosci 16:31-46.

Johnson F, Hohmann SE, DiStefano PS, Bottjer SW (1997) Neurotrophins suppress apoptosis induced by deafferentation of avian motorcortical region. J Neurosci 17:2101-2111.

Johnson JE, Oppenheim RW (1994) Keeping track of changing neurotrophic theory. Curr Biol 4:662-665.

Johnson JE, Barde Y-A, Schwab M, Thoenen H (1986) Brain-derived neurotrophic factor supports the survival of cultured rat retinal ganglion cells. J Neurosci 6:3031-3038.

Johnson JE, Haak-Frendscho M, Sugasawara R, Karasangi N (1995) Electrochemiluminescence immunoassays (ECLIA) for neurotrophins. Soc Neurosci Abstr 21:32.

Johnson JE, Forbes ME, Drum K, Anstrom J (1996) Measurements of the BDNF protein during CNS development. Soc Neurosci Abstr 22:295.

Jones KR, Farinas I, Backus C, Reichardt LF (1994) Targeted disruption of the BDNF gene perturbs brain and sensory neuron development but not motor neuron development. Cell 76:989-999.

Keizer K, Kuypers HG, Huisman AM, Dann O (1983) Diamidino yellow dihydrochloride (DY.2HCl): a new fluorescent retrograde neuronal tracer which migrates only very slowly out of the cell. Exp Brain Res 51:179-191.

Koide T, Takahashi JB, Hoshimaru M, Kojima M, Otsuka T, Asahi M, Kikuchi H (1995) Localization of trkB and low-affinity nerve growth factor receptor mRNA in the developing rat retina. Neurosci Lett 185:183-186.

Korsching S (1993) The neurotrophic factor concept: a reexamination. J Neurosci 13:2739-2748.

Kromer LF (1987) Nerve growth factor treatment after brain injury prevents neuronal death. Science 235:214-216.

Lehwalder D, Jeffrey PL, Unsicker K (1989) Survival of purified embryonic chick retinal ganglion cells in the presence of neurotrophic factors. J Neurosci Res 24:329-337.

Lewin GR, Barde Y-A (1996) Physiology of the neurotrophins. Annu Rev Neurosci 19:289-317.

Linden R, Esbérard EL (1987) Displaced amacrine cells in the ganglion cell layer of the hamster retina. Vision Res 27:1071-1076. 
Liu X, Ernfors P, Wu H, Jaenisch R (1995) Sensory but not motor neuron deficits in mice lacking NT4 and BDNF. Nature 375:238-241.

Ma Y-T, Hsieh T, Forbes ME, Johnson JE, Frost DO (1997) BDNF protein levels in developing hamster visual system. Soc Neurosci Abstr 23:329.

Mahalik TJ, Altar CA (1996) Programmed cell death in the developing rat striatum and attenuation by BDNF not NT-3. Soc Neurosci Abstr 22:996.

Mansour-Robaey S, Clarke DB, Wang YC, Bray GM, Aguayo AJ (1994) Effects of ocular injury and administration of brain-derived neurotrophic factor on survival and regrowth of axotomized retinal ganglion cells. Proc Natl Acad Sci USA 91:1632-1636.

Mey J, Thanos S (1993) Intravitreal injections of neurotrophic factors support the survival of axotomized retinal ganglion cells in adult rats in vivo. Brain Res 602:304-317.

Meyer-Franke A, Kaplan MR, Pfrieger FW, Barres BA (1995) Characterization of the signaling interactions that promote the survival and growth of developing retinal ganglion cells in culture. Neuron 15:805-819.

Okazawa H, Kamei M, Imafuku I, Kanazawa I (1994) Gene regulation of trkB and trkC in the chick retina by light/darkness exposure. Oncogene 9:1813-1818.

Oppenheim RW (1991) Cell death during development of the nervous system. Annu Rev Neurosci 14:453-501.

Oppenheim RW, Prevette D, Haverkamp LJ, Houenou L, Yin Q-W, McManaman J (1993) Biological studies of a putative avian musclederived neurotrophic factor that prevents naturally occurring motoneuron death in vivo. J Neurobiol 24:1065-1079.

Primi M-P, Clarke PGH (1996) Retrograde neurotrophin-mediated control of neurone survival in the developing central nervous system. Dev Neurosci 7:473-476.

Rabacchi SA, Ensini M, Bonfanti L, Gravina A, Maffei L (1994) Nerve growth factor reduces apoptosis of axotomized retinal ganglion cells in the neonatal rat. Neuroscience 63:969-973.

Rehen SK, Linden R (1994) Apoptosis in the developing retina: paradoxical effects of protein synthesis inhibition. Braz J Med Biol Res 27:1647-1651.

Rickman DW, Brecha NC (1995) Expression of the proto-oncogene, trk, receptors in the developing rat retina. Vis Neurosci 12:215-222.

Rodriguez-Tebar A, Jeffery PL, Thoenen H, Barde Y-A (1989) The survival of chick retinal ganglion cells in response to brain-derived neurotrophic factor depends on their embryonic age. Dev Biol 136:296-303.

Rodriguez-Tebar A, de la Rosa EJ, Arribas A (1993) Neurotrophin-3 receptors in the developing chick retina. Eur J Biochem 211:789-794.

Schwartz PM, Borghesani PR, Levy RL, Pomeroy SL, Segal RA (1997) Abnormal cerebellar development and foliation in BDNF-/- mice reveals a role for neurotrophins in CNS patterning. Neuron 19:269-281.

Sefton AJ, Lam K (1984) Quantitative and morphological studies on developing optic axons in normal and enucleated albino rats. Exp Brain Res 57:107-117.

Segal RA, Bhattacharyya A, Rua L, Alberta JA, Stephens RM, Kaplan
DR, Stiles CD (1996) Differential utilization of Trk autophosphorylation sites. J Biol Chem 271:20175-20181.

Sendtner M, Holtmann B, Kolbeck R, Thoenen H, Barde Y-A (1992) Brain-derived neurotrophic factor prevents the death of motoneurons in newborn rats after nerve section. Nature 360:757-759.

Sengelaub DR, Dolan RP, Finlay BL (1986) Cell generation, death and retinal growth in the development of the hamster retinal ganglion cell layer. J Comp Neurol 246:527-543.

Snider WD (1994) Functions of the neurotrophins during nervous system development: what the knockouts are teaching us. Cell 77:627-638.

Tay D, So K-F, Jen LS, Lau KC (1986) The postnatal development of the optic nerve in hamsters: an electron microscopic study. Dev Brain Res 30:268-273.

Thanos S, Baehr M, Barde Y-A, Vanselow J (1989) Survival and axonal elongation of adult rat retinal ganglion cells. Eur J Neurosci 1:19-26.

Tolkovsky A (1997) Neurotrophic factors in action-new dogs and new tricks. Trends Neurosci 20:1-3.

Ugolini G, Cremisi F, Maffei L (1995) TrkA, trkB, p75 mRNA expression is developmentally regulated in the rat retina. Brain Res 704:121-124.

von Bartheld CS, Heuer JG, Bothwell M (1991) Expression of nerve growth factor (NGF) receptors in the brain and retina of chick embryos: comparison with cholinergic development. J Comp Neurol 310:103-129.

von Bartheld CS, Kinoshita Y, Prevette D, Yin Q-W, Oppenheim RW, Bothwell M (1994) Positive and negative effects of neurotrophins on the isthmo-optic nucleus in chick embryos. Neuron 12:639-654.

von Bartheld CS, Williams R, Lefcort F, Clary DO, Reichardt LF, Bothwell M (1996) Retrograde transport of neurotrophins from the eye to the brain in chick embryons: roles of the p75 NTR and trkB receptors. J Neurosci 16:2995-3008.

Weibel D, Kreutzberg GW, Schwab ME (1995) Brain-derived neurotrophic factor (BDNF) prevents lesion-induced axonal die-back in young rat optic nerve. Brain Res 679:249-254.

Wetmore C, Ernfors P, Persson H, Olson L (1990) Localization of brain-derived neurotrophic factor mRNA to neurons in the brain by in situ hybridization. Exp Neurol 109:141-152.

Wyatt S, Davies AM (1993) Regulation of expression of mRNAs ending the nerve growth factor receptors p75 and trkA in developing sensory neurons. Development 119:635-648.

Yan Q, Elliott J, Snider WD (1992) Brain-derived neurotrophic factor rescues spinal motor neurons from axotomy-induced cell death. Nature 360:753-755.

Yan Q, Rosenfeld RD, Matheson CR, Hawkins N, Lopez OT, Bennett L, Welcher AA (1997) Expression of brain-derived neurotrophic factor protein in the adult rat central nervous system. Neuroscience 78:431-448.

Yang H, Leland JK, Yost D, Massey RJ (1994) Electrochemiluminescence: a new diagnostic and research tool. Biotechnology 12:193-194.

Zanellato A, Comelli MC, Dal Toso R (1993) Developing rat retinal ganglion cells express the functional NGF receptor p140trkA. Dev Biol 159:105-113. 